\title{
Is the omnivorous krill Meganyctiphanes norvegica primarily a selectively feeding carnivore?
}

\author{
Stein Kaartvedt*, Tom Larsen, Knut Hjelmseth, Maren S. R. Onsrud \\ Department of Biology, University of Oslo, PO Box 1064 Blindern, 0316 Oslo, Norway
}

\begin{abstract}
Feeding of the krill Meganyctiphanes norvegica was studied at a $120 \mathrm{~m}$ and a $200 \mathrm{~m}$ deep site in the Oslofjord, Norway. Converting stomach content of copepod mandibles and gut fluorescence into carbon equivalents suggested that the highest carbon gain was from carnivorous feeding, although contribution from herbivorous feeding was of the same order of magnitude in spring. High daytime gut fluorescence during spring suggested that sedimenting algae were efficiently cropped in deep water. On other occasions algae were exploited during nocturnal vertical migrations. In late summer, $M$. norvegica acted as a selectively feeding carnivore, primarily preying on Temora longicornis during nocturnal migrations to upper layers. Algal food was neglected at this time. During winter, the feeding conditions differed between the 2 stations. Estimated carbon equivalents of the stomach content were high at the shallowest site, and low at the deepest site. We ascribe this difference to the ability of $M$. norvegica to visually detect and exploit overwintering Calanus spp. during daytime at the $120 \mathrm{~m}$ station, while Calanus spp. overwintered below the daytime depth of M. norvegica at the $200 \mathrm{~m}$ deep station. Cyclopoid copepods were normally under-represented in the stomach contents.
\end{abstract}

KEY WORDS: Temora $\cdot$ Calanus $\cdot$ Visual feeding $\cdot$ Gut fluorescence $\cdot$ Diel vertical migration

\section{INTRODUCTION}

The krill Meganyctiphanes norvegica is a key organism in food webs of the northern Atlantic and fringing shelves, utilizing diverse food sources and being a prominent prey organism for fish, birds and marine mammals (Pearcy et al. 1979, Mauchline 1980, FalkPetersen \& Hopkins 1981). Microscopic investigations of stomach contents have revealed items such as detritus, algae, ctenophores, chaetognaths and copepod remains (e.g. Mauchline 1980, Sameoto 1980, Beyer 1992, Buchholz et al. 1995, Båmstedt \& Karlson 1998), and measurements of gut fluorescence have assessed herbivorous food intake (Simard et al. 1986, Onsrud \& Kaartvedt 1998). Some studies suggest unselective

*E-mail: stein.kaartvedt@bio.uio.no feeding by M. norvegica (Mauchline 1980, Buchholz et al. 1995), while others suggest that food items may be eaten in proportions different from ambient (Båmstedt $\&$ Karlson 1998). To what extent $M$. norvegica performs selective feeding remains unresolved.

Although clearly omnivorous, particularly in the southern parts of its range (Mayzaud et al. 1999, Virtue et al. 2000), the morphology of its mouth-parts (Mauchline 1980), biochemical composition (Sargent \& FalkPetersen 1981, Falk-Petersen et al. 2000) and stomach contents (Sameoto 1980, Båmstedt \& Karlson 1998) have led to the conclusion that Meganyctiphanes norvegica is primarily a carnivore in northern waters. However, no study seems to have quantified the relative importance of phytoplankton and zooplankton prey in a common currency.

In this study, we concurrently address herbivorous and carnivorous feeding of Meganyctiphanes norvegica 
under a range of contrasting environmental conditions. We compare species composition of copepods in krill stomachs and in the water column from different locations and during different times of day and year. By converting both copepod prey and gut fluorescence into carbon units, we aim to assess the relative importance of phytoplankton and copepods as food.

\section{MATERIALS AND METHODS}

Study area and periods. The study was conducted at 2 sites in the same fjord system (Oslofjorden, Norway). At an inner, $120 \mathrm{~m}$ deep station (location 'Steilene'; $\left.59^{\circ} 48^{\prime} \mathrm{N}, 10^{\circ} 34^{\prime} \mathrm{E}\right)$, sampling was carried out during 29 to 30 November 1995, 26 to 27 March, 6 to 7 June and 14 to 15 August 1996. At an outer, $200 \mathrm{~m}$ deep station $\left(59^{\circ} 38^{\prime} \mathrm{N}, 10^{\circ} 38^{\prime} \mathrm{E}\right)$ in the Drøbak sound, delineating the inner and outer Oslofjord, investigations were carried out on 30 to 31 May, 21 to 22 August and 12 to 13 November 1996. We hereafter refer to these stations as Stn S ('shallow') and Stn D ('deep'), respectively. If not otherwise stated, the same methods were applied, though modified to the different depths at the 2 stations.

Hydrography and chlorophyll a. Temperature and salinity profiles were obtained with a Neil Brown Mark III CTD. Water samples for measurements of water column chl a were collected with Niskin bottles. Subsamples of $100 \mathrm{ml}$ were filtered onto Whatman glass microfibre filters $(\mathrm{GF} / \mathrm{F})$. The filters were immediately frozen, and analyzed for extracted chl a by a Turner Designs fluorometer according to Strickland \& Parsons (1972).

Mesozooplankton was collected using a WP2 net (Working Party no. 2; $57 \mathrm{~cm}$ diameter) with $200 \mu \mathrm{m}$ mesh size, fitted with a closing mechanism. The net was hauled vertically at $50 \mathrm{~cm} \mathrm{~s}^{-1}$, and filtered volume was estimated by multiplying towing distance with net mouth area. The samples were preserved in $4 \%$ formalin. Two replicate series were taken day and night, but to reduce work only 1 daytime series from each cruise was analyzed for taxonomic composition. Subsamples were obtained by a Lea-Wiborg divider, and subsamples of at least 400 copepods were counted. Krill and fish distribution. Simrad EK 500, $120 \mathrm{kHz}$ and $38 \mathrm{kHz}$ split-beam echo-sounders were used for studies of krill and fish, but only the results at $120 \mathrm{kHz}$ are presented here. The transducer depth was $1.8 \mathrm{~m}$, which is accounted for in the software. Data acquisition and post-processing was achieved using the EP500 software (Lindem \& Al Houari 1993). Logging failed in March, and the results from this survey are presented by sections of echograms that were continuously displayed by a printer.
Previous studies at Stn S have identified Meganyctiphanes norvegica as the main acoustic target of a dielly migrating scattering layer (SL) that is much more strongly displayed at 120 than at $38 \mathrm{kHz}$ (Onsrud \& Kaartvedt 1998). The present investigation confirmed those results: 62 net tows outside this layer provided only $3 M$. norvegica, while 162 tows within the layer gave $832 M$. norvegica, with no evident alternative planktonic scatterers present. A varying amount of fish did, however, occur among the krill, sometimes acoustically masking the krill distribution. A corresponding SL at Stn D was ascribed to krill. More than $90 \%$ of the individuals captured during this investigation were $>30 \mathrm{~mm}$, confirming that these targets will be revealed at $120 \mathrm{kHz}$ (Greene et al. 1991).

Meganyctiphanes norvegica was collected day and night. During sampling at Stn S, the RV 'Trygve Braarud' was anchored at a fixed position and $M$. norvegica was sampled by vertical net tows, using a modified Nansen net of $103 \mathrm{~cm}$ diameter (Kirkerud 1975). To reduce net-avoidance, the Nansen-net was equipped with a strobe light (Onsrud \& Kaartvedt 1998), but this light source failed in August. At Stn D, sampling was done with a 3-foot Isaac-Kidd Midwater Trawl (IKMT) towed at 4 knots. An autonomous CTD (Gytre STD) was attached to the trawl for mapping of the vertical towing profile, except for November when sampling depths were estimated based on relationships between wire length and depth established during the previous cruises. The catches of krill cannot be considered as quantitative, but served their purpose of revealing the main patterns of the vertical distributions, allowing species identification in the acoustic scattering layer, and providing individuals for stomach analysis. To get a sufficient number of stomachs, individuals captured with the WP net were also included.

Krill feeding. In November 1995, catches were split in 2 , and 1 half was frozen $\left(-20^{\circ} \mathrm{C}\right)$ for later analysis of stomach pigment, and one half preserved in $4 \%$ formalin for microscopic examination of stomach content. For the other surveys, the procedure was changed so that all individuals were frozen, stomachs and hindgut were first examined for pigments, and the same stomachs were thereafter examined microscopically. In total, 1069 individuals were investigated for gut pigments and 660 in the more labor-intensive microscopic analysis.

In the laboratory, stomach and hindgut were dissected from the frozen individuals, put into a test tube with $10 \mathrm{ml} 90 \% \mathrm{MgCO}_{3}$ buffered acetone, and extracted for $24 \mathrm{~h}$ in the dark at $4^{\circ} \mathrm{C}$ (Simard et al. 1986). Fluorescence was measured with a Turner Designs fluorometer. Fluorescence background levels due to stomach tissues were considered to be negligible (Simard et al. 1986). Content of chl $a$ and the chloro- 
phyll equivalents of pheopigment were calculated according to equations in Dagg \& Walser (1987). These values were added to give total pigments.

Beyer (1992) concluded that Meganyctiphanes norvegica might often only eat the soft parts of their prey. However, Båmstedt \& Karlson (1998) showed that identification of mandibles from stomach content can be used to assess number of copepods eaten, since in most cases (ca $80 \%$ ) M. norvegica engulfed the entire prey and the turnover time of mandibles was similar to that of other parts of the prey (i.e. mandibles did not accumulate in the stomach). Stomachs were examined microscopically at $100 \times$ and $400 \times$ magnification. Species and stage identification of prey copepods were done based on the shape and size of their mandibles (Sars 1903, 1918, Karlson \& Båmstedt 1994, Ottesen 1995). Unidentified mandibles were often damaged or partly covered by other material.

In the statistical testing of feeding patterns, the nonparametric Mann-Whitney U-test was applied (Zar 1996).

For comparisons of the dietary contribution from carnivorous and herbivorous feeding, ingested copepods and gut fluorescence were converted to carbon equivalents. We used a factor of 50 for conversion of total pigment to carbon, as previously applied by Dagg \& Gill (1980) in estimates of copepod feeding, not accounting for potential gut degradation of pigments (cf. Perissinotto \& Pakhomov 1996). We used a dry weight of Calanus CV of $190 \mu \mathrm{g}$, as found for individuals in Oslofjorden (Olsen 1996), scaled the size of the other copepods according to Wiborg (1954) and assumed a $50 \%$ carbon content (Omori \& Ikeda 1984). Unidentified copepods were allocated to the size of Pseudocalanus. Each matched pair of mandibles was assumed to represent the ingestion of a single copepod (Karlson \& Båmstedt 1994).

\section{RESULTS}

\section{Hydrography}

Salinities and temperatures were fairly homogenous below 20 m (Figs. 1 \& 2), although vertical gradients reached somewhat deeper at Stn D, especially for temperature in November (Fig. 2). The most marked hydrographic gradients of the upper layer occurred in August.

\section{Chlorophyll a}

Shallow chl a maxima occurred in November (Figs. 1 \& 2), but some chl a also was recorded in the deeper

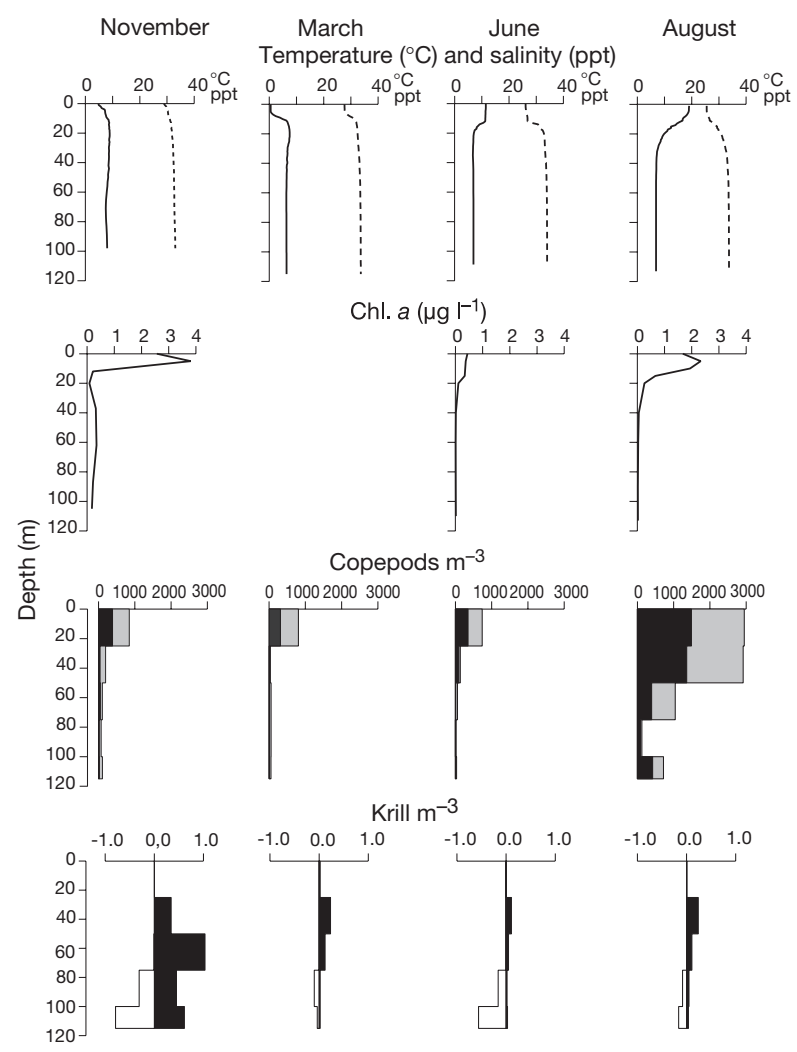

Fig. 1. Vertical distribution of temperature (solid line) and salinity (stippled line); chl $a_{\text {; }}$ copepods (cyclopoids black; calanoids shaded) and Meganyctiphanes norvegica at day (open) and night (black) at Stn S
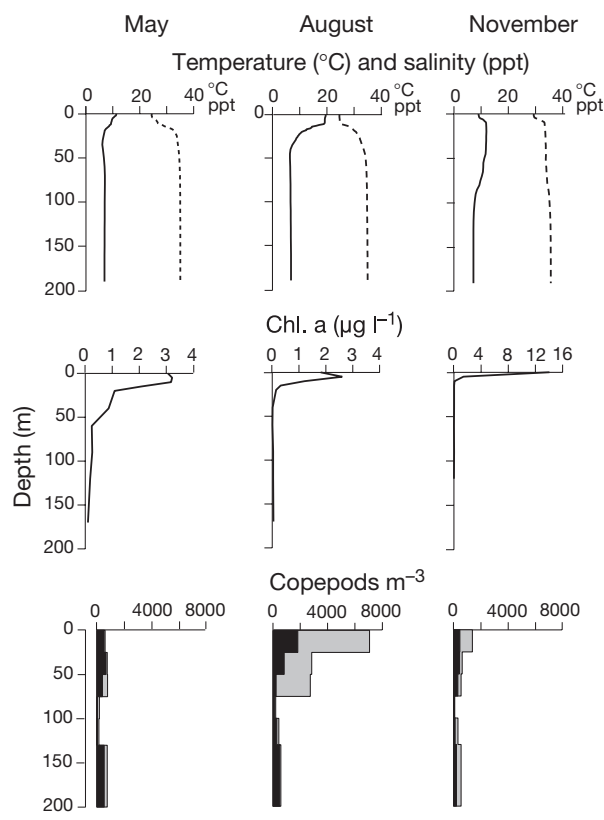

Fig. 2 Vertical distribution of temperature (solid line) and salinity (stippled line); chl $a$ and copepods (cyclopoids black; calanoids shaded) at $\operatorname{Stn} \mathrm{D}$ 
part of the water column at Stn S (Fig. 1). Samples were lost for March, but measurements in the surface water $4 \mathrm{~d}$ prior to our cruise gave very high values (21.5 $\mu \mathrm{g}$ chl a $\mathrm{l}^{-1}$; Jan Magnusson, Norwegian Institute of Water Research, pers. comm.). Results for May were characterized by fairly high values relatively deep into the water column (Fig. 2). Water column chl a content was very low in June (Fig. 1), while chl a was quite abundant in the upper 10 to $15 \mathrm{~m}$ in August at both sites (Figs. 1 \& 2).

\section{Copepods}

Copepods were usually most abundant in the upper $25 \mathrm{~m}$, while numbers were always low between 75 and 100 m (Figs. 1 \& 2).

Oithona was normally the numerically dominant genus, although Oncaea prevailed at Stn D in May (Tables 1 and 2). Temora longicornis was abundant in August at both sites. Overwintering Calanus spp. were recorded in the deep water in November, in relatively low numbers at Stn $\mathrm{S}$, and relatively high numbers at Stn D the subsequent year.

\section{Krill and fish distribution}

The distribution of scattering layers ascribed to Meganyctiphanes norvegica remained below $70 \mathrm{~m}$ at day, ascending at night (Figs. $3 \& 4$ ). At Stn $\mathrm{S}$, the ascent seemed to be terminated at about $20 \mathrm{~m}$ depth, except for August (Fig. 3). The net tows displayed a corresponding day-distribution (Fig. 1), but generally suggested a deeper night distribution than the echograms. At Stn D, M. norvegica migrated all the way to the surface at night in August and November (Fig. 4, Table 3). M. norvegica could not be located acoustically in May when fish echoes were prominent (not shown),
Table 1. Taxonomic composition of copepods $\mathrm{m}^{-3}$ in catches by WP2 net at Stn S

\begin{tabular}{|c|c|c|c|c|c|c|c|c|c|c|}
\hline $\begin{array}{l}\text { Depth } \\
\text { (m) }\end{array}$ & & \multicolumn{3}{|r|}{$\underbrace{5}$} & $0 \%$ & $0^{5}$ & $e^{e^{e^{v^{0^{0}}}}}$ & \multicolumn{2}{|c|}{$a^{a^{v^{v^{5}}}}$} & $x^{20}$ \\
\hline \multicolumn{11}{|c|}{ November } \\
\hline $0-25$ & 4 & - & 124 & 30 & 17 & 365 & 286 & 13 & - & - \\
\hline $25-50$ & 9 & 2 & 3 & - & 2 & 38 & 33 & 105 & - & - \\
\hline $50-75$ & 2 & 26 & - & - & 2 & 44 & 12 & 14 & 2 & 1 \\
\hline $75-100$ & - & 45 & 1 & _- & - & 12 & 1 & 10 & - & - \\
\hline $100-115$ & - & 60 & 1 & - & 4 & 12 & 2 & 23 & - & 2 \\
\hline \multicolumn{11}{|l|}{ March } \\
\hline $0-25$ & 2 & 1 & 2 & 9 & 24 & 286 & 138 & 6 & - & - \\
\hline $25-50$ & - & 3 & - & - & 1 & 2 & 8 & 17 & 1 & - \\
\hline $50-75$ & - & 4 & - & - & 3 & 2 & 15 & 25 & 4 & 1 \\
\hline $75-100$ & - & 6 & - & - & 2 & 2 & 6 & 30 & 4 & 2 \\
\hline $100-115$ & - & 4 & - & - & 1 & 3 & 15 & 19 & 1 & 4 \\
\hline \multicolumn{11}{|l|}{ June } \\
\hline $0-25$ & 4 & - & - & 97 & 121 & 229 & 140 & 16 & - & - \\
\hline $25-50$ & - & 1 & - & 2 & 67 & 31 & 77 & 22 & - & - \\
\hline $50-75$ & - & 2 & - & - & 5 & 4 & 6 & 36 & - & - \\
\hline $75-100$ & - & 4 & - & - & - & 1 & 1 & 11 & - & 3 \\
\hline $100-115$ & - & - & - & 1 & 4 & 3 & 5 & 17 & 1 & 2 \\
\hline \multicolumn{11}{|l|}{ August } \\
\hline $0-25$ & 23 & 67 & 78 & 144 & 44 & 1446 & 63 & 6 & - & - \\
\hline $25-50$ & 2 & 21 & 6 & 707 & 337 & 1024 & 11 & 2 & - & - \\
\hline $50-75$ & 1 & 33 & 1 & 472 & 13 & 381 & 9 & 1 & - & 1 \\
\hline $75-100$ & 1 & 10 & 1 & 4 & 3 & 86 & 2 & - & - & - \\
\hline $100-115$ & 7 & 21 & 7 & 104 & 44 & 377 & 1 & 3 & - & 1 \\
\hline
\end{tabular}

Table 2. Taxonornic composition of copepods $\mathrm{m}^{-3}$ in catches by WP2 net at Stn D

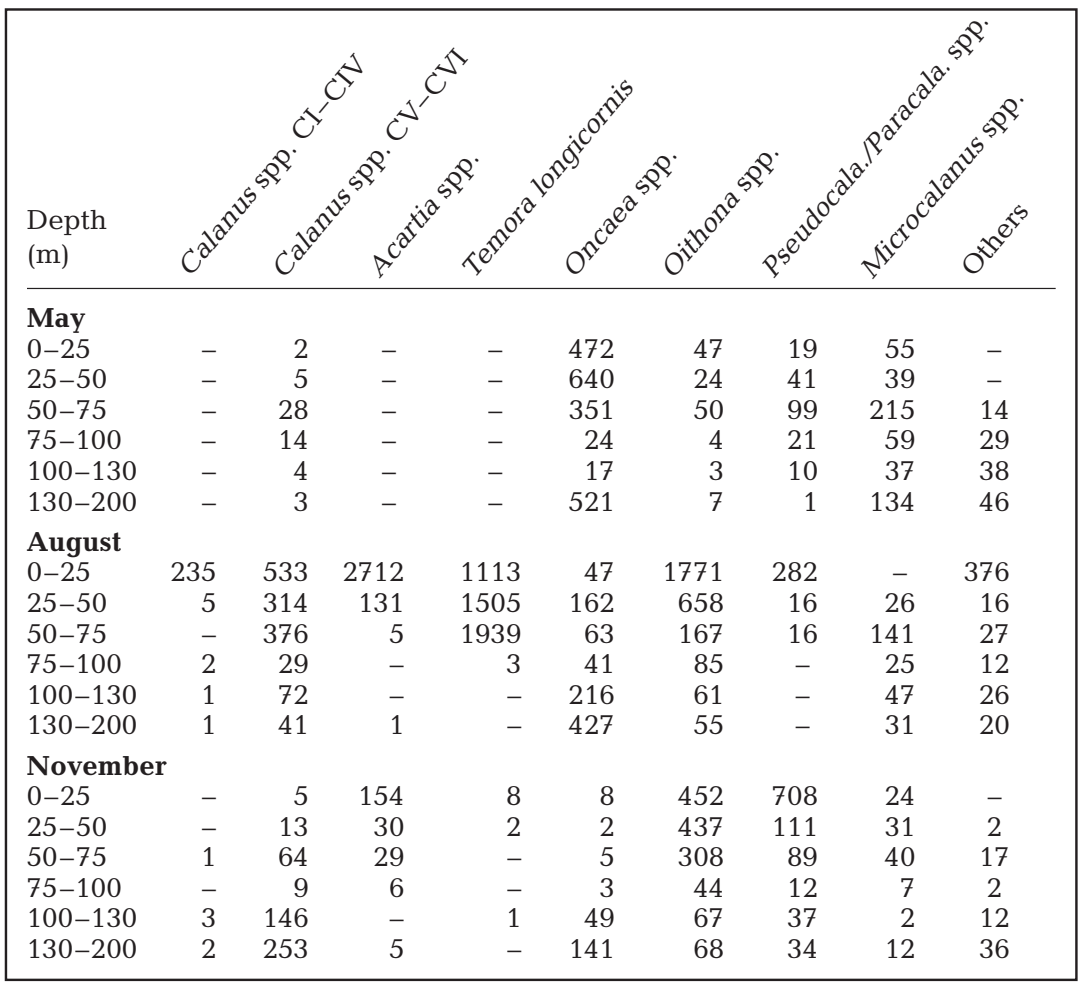



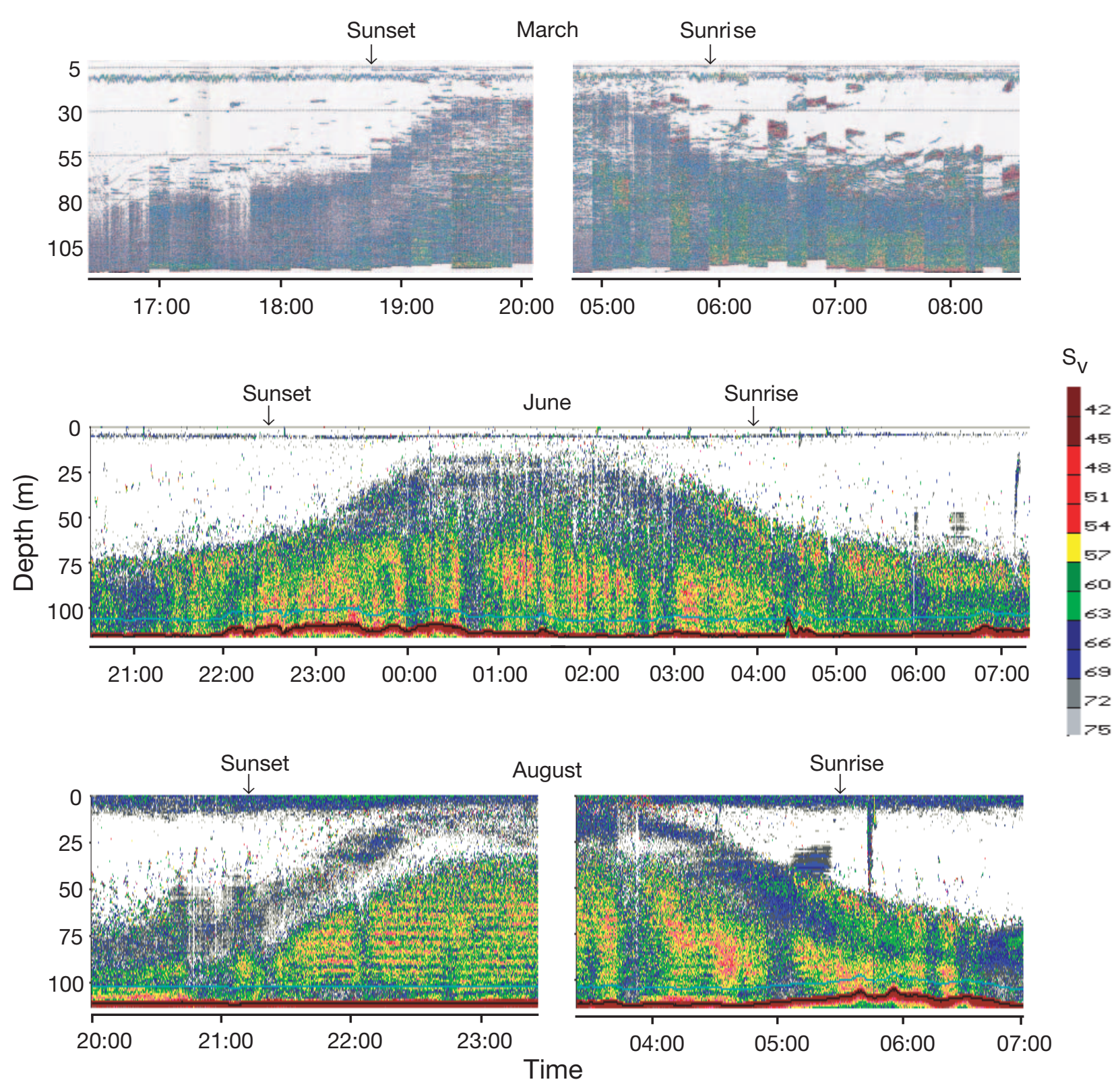

Fig. 3. Acoustic records $(120 \mathrm{kHz})$ at $\mathrm{Stn} \mathrm{S}$ in the afternoon and in the morning. Color bar denotes volume backscattering $\left(S_{\mathrm{v}}\right)$

but then appeared to remain below $100 \mathrm{~m}$ at day, migrating up to about $20 \mathrm{~m}$ at night (Table 3).

Fish records were otherwise most common at Stn S. At this shallower location, fish ascending from the bottom at night, appearing as a 'dome' below the krill SL, were particularly evident in June and August (Fig. 3). Other fish traces were associated with the krill both day and night, carrying out corresponding diel migrations. Fish schools occurred above the krill layer during the day, best seen after sunrise in March (Fig. 3), and were also very prominent in November (results presented by Onsrud \& Kaartvedt 1998). These fish dispersed among the vertically migrating krill at night.

\section{Krill feeding}

Stomachs of Meganyctiphanes norvegica contained much pigment, but also some mandibles, in March and May, and many mandibles, but little pigment, in August (Fig. 5). The lowest stomach content appeared in June and November, yet individuals captured at Stn $\mathrm{S}$ in November had reasonable high stomach content (Fig. 5).

Diel differences (Fig. 5) included gut fluorescence that was significantly higher at day than at night in March and June ( $p<0.01)$, while gut fluorescence increased at night at both sites in November $(\mathrm{p}<$ 


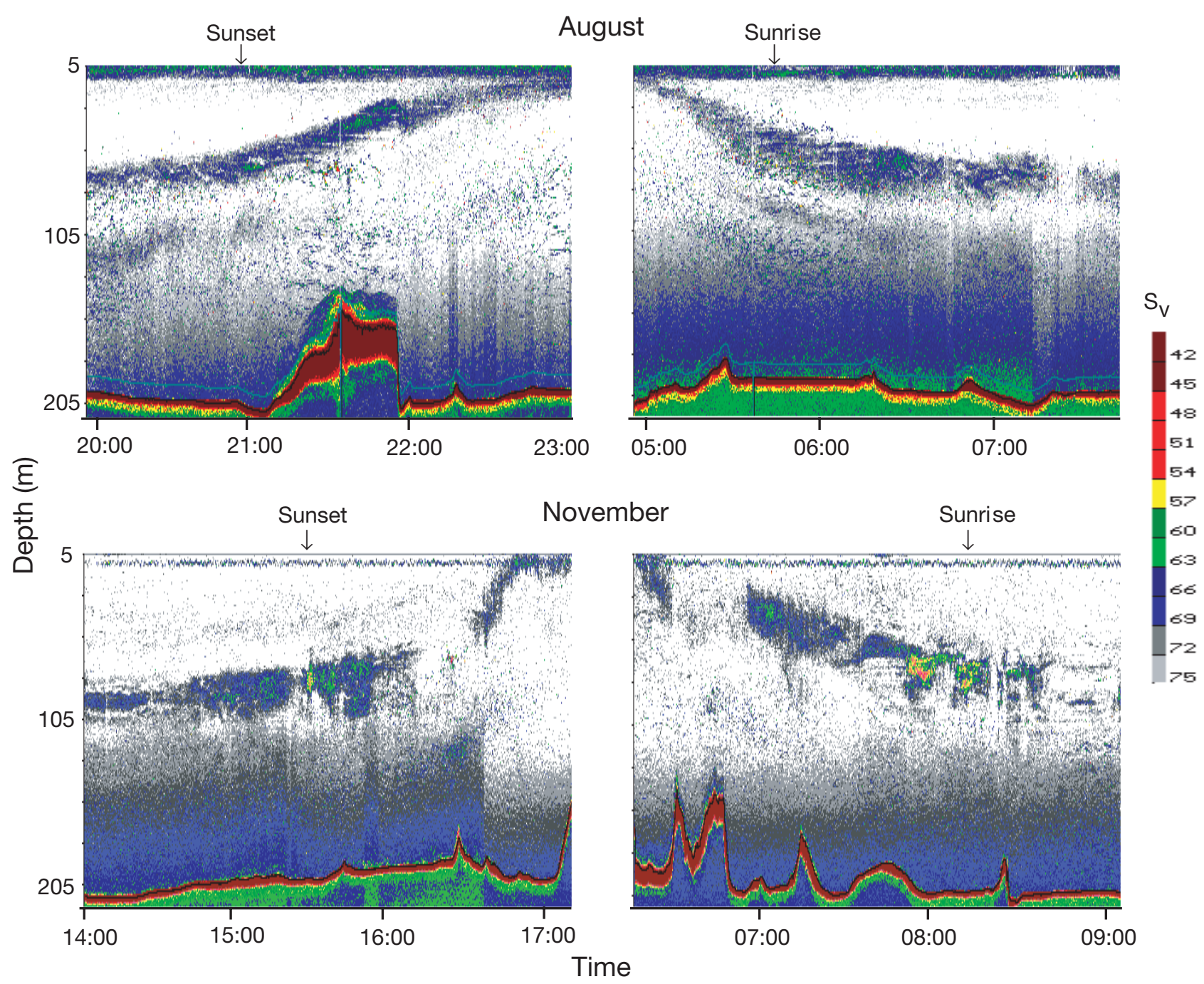

Fig. 4. Acoustic records $(120 \mathrm{kHz})$ at $\mathrm{Stn} \mathrm{D}$ in the afternoon and in the morning. Color bar denotes volume backscattering $\left(S_{\mathrm{v}}\right)$

0.01). Also, a very slight (not visually apparent from Fig. 5) yet significant increase in gut fluorescence occurred at night at Stn D in August $(p<0.01)$. Numbers of mandibles increased at night in August at both sites $(\mathrm{p}<0.01)$, and at Stn D in November $(\mathrm{p}<0.01)$.

\section{Taxonomic prey composition}

Calanus spp. and Temora longicornis (particularly abundant in August) were major prey organisms, and were normally over-represented in the diet compared to their abundance in the water column (Figs. 6 \& 7). Although cyclopoid copepods were always common in the water column, they were never identified among the stomach content at Stn S (Fig. 6). Cyclopoids were also strongly under-represented at Stn D, except for Oithona spp. in November. Oncaea spp. were never identified from the Meganyctiphanes stomach contents in this investigation.

At Stn S, Calanus occurred significantly more frequently in the stomach content during day than at night in November and March $(\mathrm{p}<0.05)$. Numbers of Temora longicornis increased significantly at night at both stations in August $(\mathrm{p}<0.001)$, and at night at Stn D in November $(p<0.05)$. Acartia spp. also increased in the stomach content at night in August (Stn $D_{i} p<0.05$ ), when this prey organism was particularly abundant in the upper $25 \mathrm{~m}$ at that location (Table 2). In November, Acartia spp. were identified only from the stomach content at night (Fig. 7). Numbers of Oithona spp. increased significantly at night in November $(\mathrm{p}<0.01)$. 
Table 3. Meganyctiphanes norvegica. Catches in IKMT-hauls at Stn D given as number of individuals per nautical mile, or in liters (l)

\begin{tabular}{|c|c|c|c|c|c|c|c|c|}
\hline \multicolumn{3}{|c|}{ May - } & \multirow[b]{2}{*}{$\begin{array}{l}\text { Time } \\
\text { (start) }\end{array}$} & \multirow{2}{*}{$\begin{array}{l}\text { - August - } \\
\text { Depth } \\
\text { (m) }\end{array}$} & \multirow[b]{2}{*}{$\begin{array}{c}\text { Catch } \\
\left(\mathrm{krill} \mathrm{nm}^{-1}\right)\end{array}$} & \multirow[b]{2}{*}{$\begin{array}{l}\text { Time } \\
\text { (start) }\end{array}$} & Novembe & \multirow[b]{2}{*}{$\begin{array}{c}\text { Catch } \\
\left(\mathrm{krill} \mathrm{nm}^{-1}\right)\end{array}$} \\
\hline $\begin{array}{l}\text { Time } \\
\text { (start) }\end{array}$ & $\begin{array}{l}\text { Depth } \\
\text { (m) }\end{array}$ & $\begin{array}{c}\text { Catch } \\
\left(\mathrm{krill} \mathrm{nm}^{-1}\right)\end{array}$ & & & & & $\begin{array}{l}\text { Depth } \\
\text { (m) }\end{array}$ & \\
\hline \multicolumn{9}{|l|}{ Day } \\
\hline $12: 05$ & $80-70$ & - & $15: 00$ & $87-71$ & - & $15: 40$ & 75 & 250 \\
\hline $13: 10$ & $97-95$ & - & $16: 50$ & $90-80$ & 100 & $08: 45$ & 80 & - \\
\hline $14: 10$ & $127-124$ & 70 & $18: 10$ & $113-105$ & 160 & 09:15 & 100 & 1.01 \\
\hline $15: 07$ & 158-152 & 40 & 20:30 & $180-170$ & 20 & $11: 30$ & 107 & $0.9 \mathrm{l}$ \\
\hline \multirow[t]{2}{*}{$08: 40$} & $108-100$ & 40 & 06:55 & $69-67$ & $0.8 \mathrm{l}$ & 12:05 & 150 & - \\
\hline & & & 07:55 & $57-55$ & 10 & & & \\
\hline \multicolumn{9}{|l|}{ Night } \\
\hline 01:00 & $5-4$ & - & $21: 50$ & $33-31$ & 300 & $16: 45$ & 45 & 0.61 \\
\hline $01: 35$ & $28-27$ & 190 & $23: 00$ & $4.3-3.4$ & 30 & $22: 45$ & 8 & 3.31 \\
\hline \multirow[t]{6}{*}{$02: 10$} & $47-46$ & 30 & 03:10 & $15-14$ & 370 & $23: 35$ & 5 & 3.31 \\
\hline & & & 04:20 & $44-42$ & 290 & 02:00 & 25 & 2.41 \\
\hline & & & $05: 35$ & $150-140$ & 90 & $04: 15$ & 30 & 6.01 \\
\hline & & & & & & 06:05 & 35 & $3.2 \mathrm{l}$ \\
\hline & & & & & & $06: 45$ & 5 & 120 \\
\hline & & & & & & 08:00 & 60 & \\
\hline
\end{tabular}

\section{DISCUSSION}

\section{Herbivorous feeding}

The high stomach pigment content of Meganyctiphanes norvegica during spring concurred with the highest quantity of water column chl a. However, differences between cruises were much more pronounced in the diet than in the environment. Surface-integrated chl a levels at Stn D varied by a factor of only 2 to 4

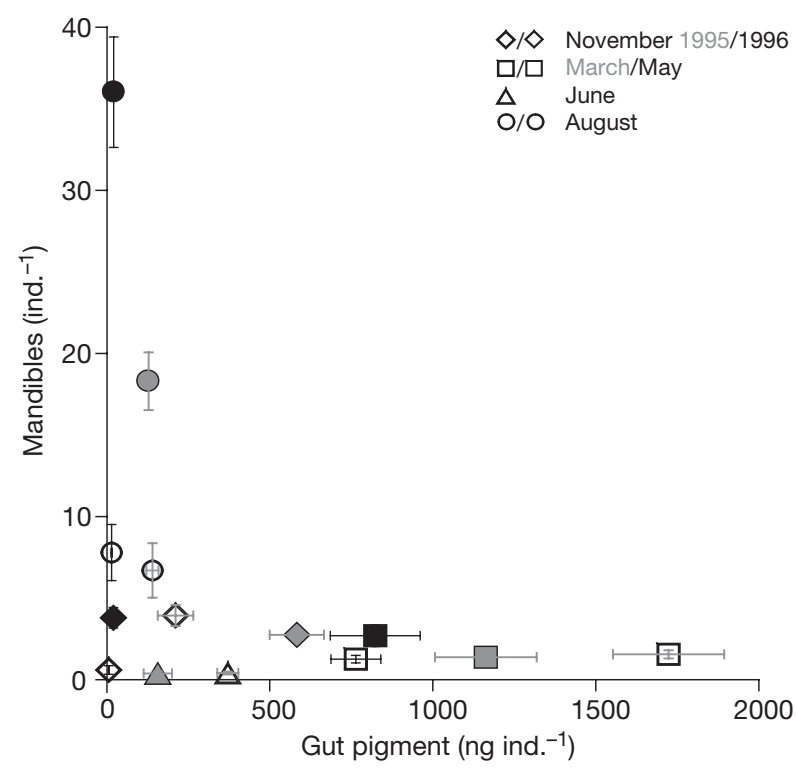

Fig. 5. Meganyctiphanes norvegica. Average gut fluorescence and stomach content of mandibles at day (open) and night (filled) at Stn S (gray) and Stn D (black). Error bars denote SE between the surveys, while stomach pigments varied by a factor of 50 to 100 (Hjelmseth 1998).

Access to algae would be best subsequent to the nocturnal ascent, but this was not always reflected in the stomach content. During spring, gut fluorescence was high at day. To some extent, daytime records may have reflected remnants from previous nocturnal feedings, as gut fluorescence was particularly high early in the morning (cf. Onsrud \& Kaartvedt 1998). Furthermore, although we focus on diel patterns it should be noted that marked and significant tow-to-tow variations were also recorded during both tows night and day (Hjelmseth 1998). Regardless, algae were exploited at depth, evidenced by high gut fluorescence even late in the day (e.g. exceeding $1000 \mathrm{ng}$ ind.- ${ }^{-1}$ as average for krill captured in May, $11 \mathrm{~h}$ after sunrise; Hjelmseth 1998). Though ambient concentrations of sedimenting algae appeared to be relatively low in May (ca. $0.1 \mu \mathrm{g} \mathrm{l}^{-1}$ ), krill can possibly utilize micro patches (e.g. Price 1989, Atkinson \& Snÿder 1997) and aggregates (Dilling et al. 1998). High records of gut fluorescence even at relatively low ambient concentration in the daytime habitat suggest that Meganyctiphanes norvegica is able to exploit efficiently much lower average algal concentrations than established from experimental studies (McClatchie 1985).

High daytime gut content of algae during spring in Oslofjorden was also observed by Onsrud \& Kaartvedt (1998), and has furthermore been recorded during bloom periods at other times of year (pers. obs.). Otherwise, such findings contrast with most reports, which normally link herbivorous feeding of Meganyctiphanes norvegica with diel vertical migration to shallow depths at night (Mauchline \& Fisher 1969, Sameoto 
Water column
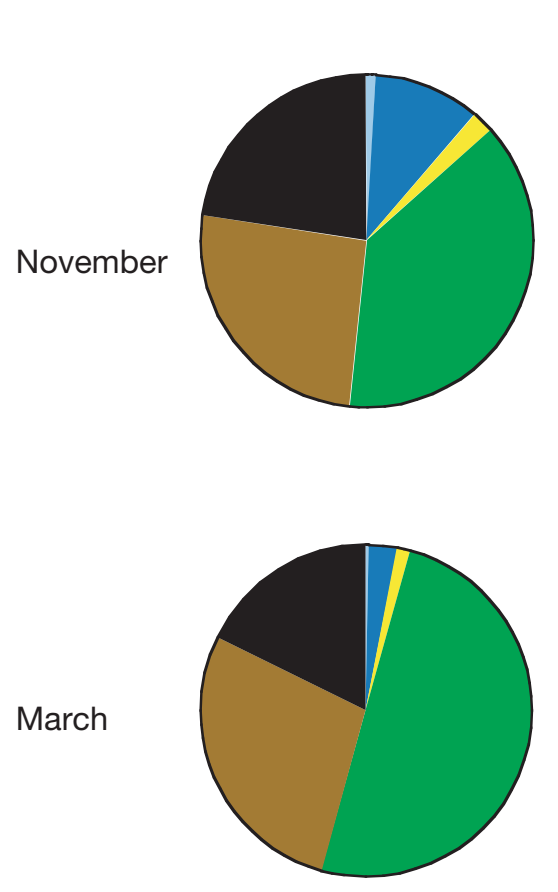

March
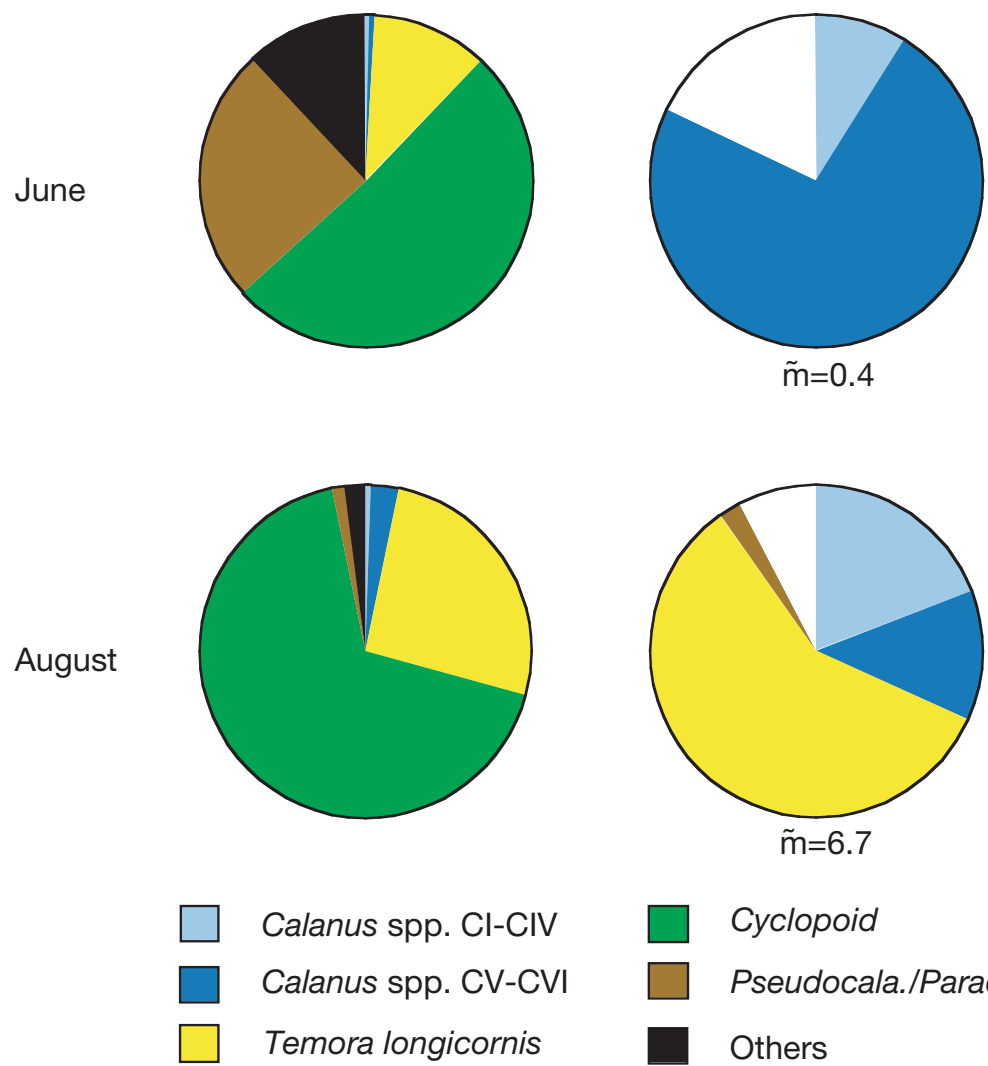

Krill stomachs
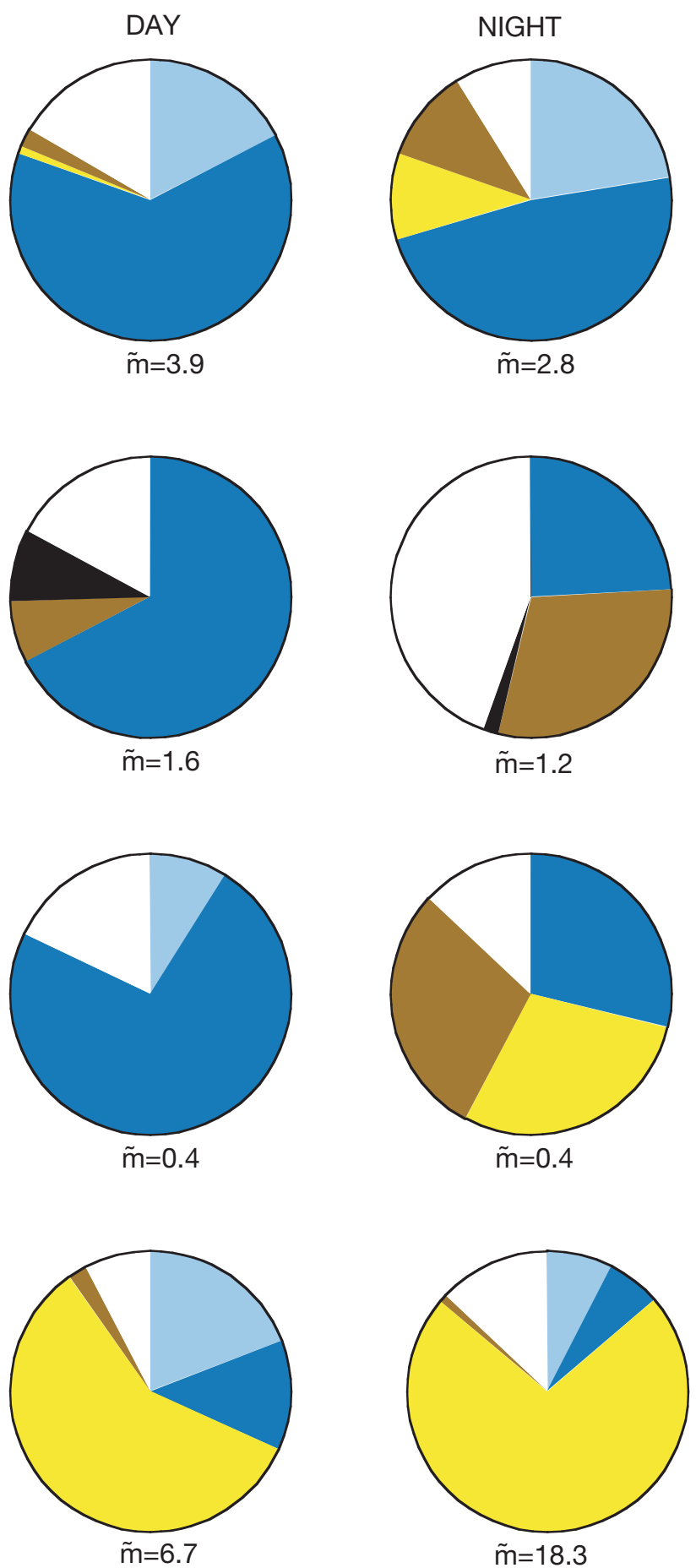

$\square$ Cyclopoid

Pseudocala./Paracala. spp.

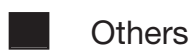

Fig. 6. Taxonomic composition of copepods in the water column and in stomachs from Meganyctiphanes norvegica captured at Stn $\mathrm{S}$ during the day and at night. $\tilde{\mathrm{m}}=$ average number of mandibles per stomach 
Water column

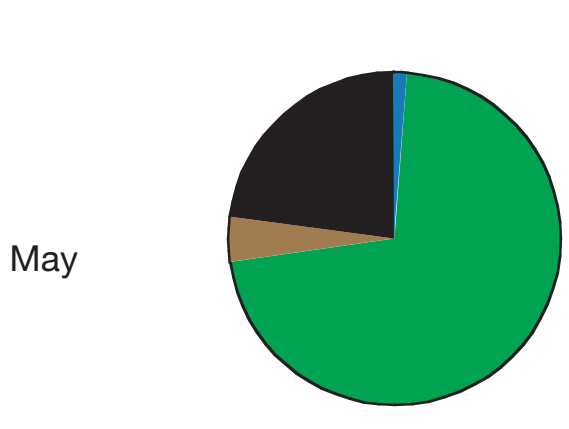

August

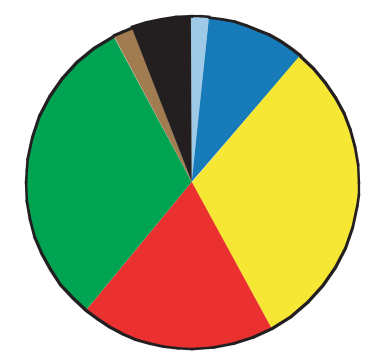

November

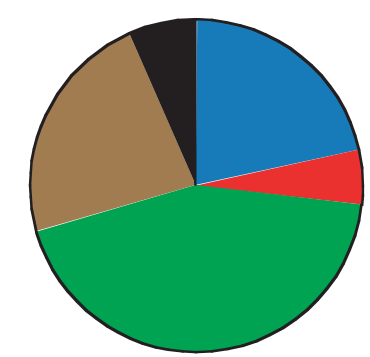

\section{Krill stomachs}

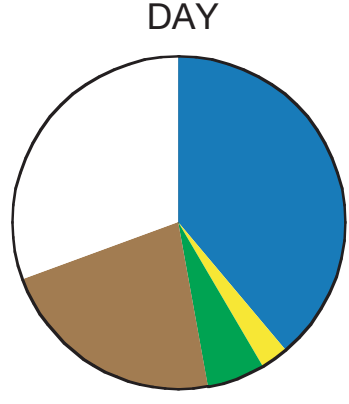

$\tilde{\mathrm{m}}=1.2$

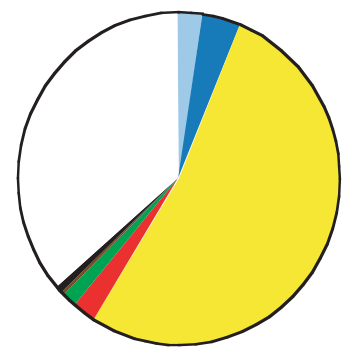

$\tilde{\mathrm{m}}=7.8$

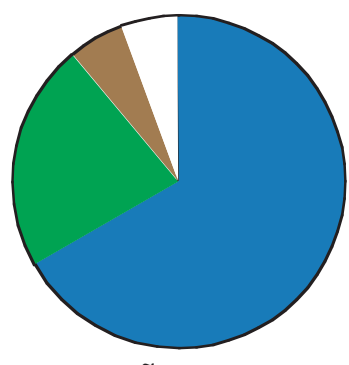

$\tilde{\mathrm{m}}=0.6$

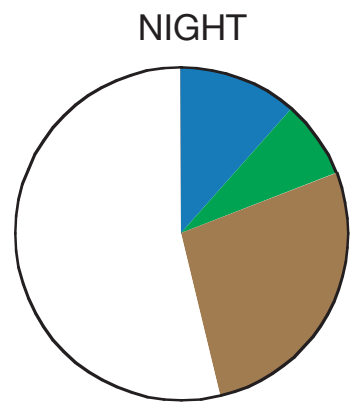

$\tilde{\mathrm{m}}=2.7$

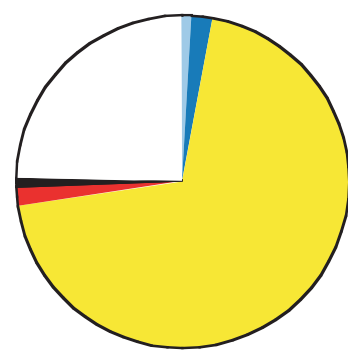

$\tilde{\mathrm{m}}=36.0$

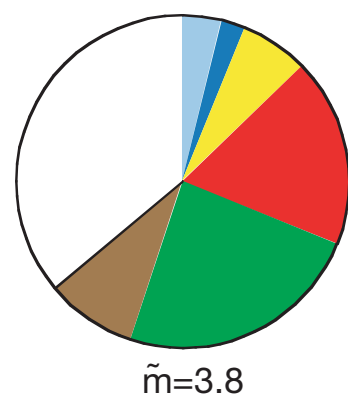

Others

$\square \quad$ Not identified

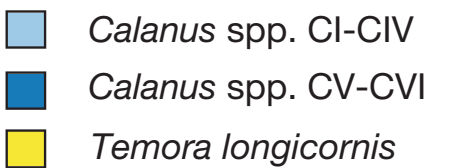

$\square$ Acartia spp.

Cyclopoid Pseudocala./Paracala. spp.

Fig. 7. Taxonomic composition of copepods in the water column and in stomachs from Meganyctiphanes norvegica captured at Stn D during the day and at night. $\tilde{\mathrm{m}}=$ average number of mandibles per stomach

1980, Simard et al. 1986, Onsrud \& Kaartvedt 1998). In August, dielly migrating $M$. norvegica neglected the reasonably rich quantity of algae in upper water, exclusively aiming for copepod prey. The slight, yet statistically significant nocturnal increase in gut fluorescence may have been caused by the stomach content of their prey (cf. Gibbons 1993). Our results from November, however, concur with the notion of nocturnal grazing in upper layers by vertically migrating individuals. In sum, our data underscore that $M$. norvegica is very versatile in its ability and motivation to exploit algal food.

\section{Prey selection}

Carnivorous feeding was selective. Notably, there was an apparent selection for Temora longicornis and 
Calanus spp. and selection against cyclopoid copepods. In August, Meganyctiphanes norvegica at both stations largely focused on 1 particular prey species, T. longicornis, which was harvested during the nocturnal ascent. Several mechanisms can account for overrepresentation of this prey item. First, T. longicornis moves continuously (Ohman 1988), which would give a hydrodynamic signal that a predator may take advantage of. Secondly, this pigmented species should be more easily spotted than transparent prey if $M$. norvegica applied visual senses in prey recognition (cf. Torgersen 2001). Thirdly, Temora spp. occur particularly patchily (Goswami \& Padmavati 1996), and focusing on patchy prey may be a requirement to obtain sufficient food when foraging on small copepods (McClatchie 1985). Lastly, Viitasalo et al. (1998) found that T. longicornis displayed particularly low escape reactions towards a mysid predator. We cannot discriminate between the relative importance of these factors.

In contrast to the mainly nocturnal predation on Temora longicornis, predation on overwintering Calanus spp. largely occurred during the day. This food source was best exploited at the shallowest site, even though our study at this location was carried out during a year of particularly low abundance of overwintering Calanus spp. (cf. Vedal 1997, Bagøien et al. 2000). Higher daytime feeding has indeed been recorded at the same location in other years (Onsrud \& Kaartvedt 1998, Bagøien et al. 2000; see next section). In contrast, Meganyctiphanes norvegica at the $200 \mathrm{~m}$ deep station displayed relatively low daytime feeding on Calanus spp. during the subsequent winter, even though abundance of overwintering Calanus spp. was considerably higher. We ascribe this discrepancy between locations to the differing topography, which then sets different constraints for visual predation by $M$. norvegica. Calanus spp. become concentrated in the daytime habitat of M. norvegica in the $120 \mathrm{~m}$ deep basin so that their vertical distributions overlap. At the deeper site, Calanus spp. overwinter below the daytime habitat of $M$. norvegica, i.e. probably below depths where $M$. norvegica can search efficiently for this potential food source by sight. Experimental studies indeed suggest that $M$. norvegica is a visual predator, with reduced predation rate on Calanus in darkness (Torgersen 2001). Visual senses would be particularly important for detection of non-moving, dormant copepods like overwintering Calanus spp.

The suggested importance of visual feeding may explain why Meganyctiphanes norvegica left abundant, probably dormant copepod prey at night for foraging on more active, shallow-living copepods or grazing on phytoplankton. Other studies have also noted that $M$. norvegica may leave abundant copepod prey during nocturnal ascent (Sameoto 1980, Onsrud \&
Kaartvedt 1998). Sameoto (1980) suggested that a varied diet was necessary to satisfy nutritional needs. The alternative interpretation that visual search is hampered at night implies that previous notions of euphausids capturing zooplankton only if they bump into the feeding appendages during normal filtering motions (e.g. as summarized by Mauchline 1980) should be rejected (see also Price et al. 1988). Such filter-feeding is furthermore incompatible with the results from August, when large numbers of copepods were eaten in chl a-rich water without much increase in gut fluorescence.

The low occurrence of cyclopoid copepods in the diet was striking considering their abundance in the water column. Correspondingly, Atkinson \& Snÿder (1997) found that juvenile Antarctic krill, Euphausia superba, had lower clearance rate on cyclopoid copepods than on calanoid copepods of similar size. It is possible that a different search pattern is required to capture the small, slow and torpid cyclopoids (cf. Gonzáles \& Smetacek 1994) compared to the normally larger and more active calanoids. In contrast, Oithona spp. seemed to be a preferentially selected prey organism in investigations of the smaller Euphausia lucens and E. hanseni (Barange et al. 1991, Gibbons et al. 1991, Gibbons 1993). These species hardly captured larger copepods. The preference for Oithona spp. was explained by its more poorly developed escape behavior from these primarily filter-feeding krill.

\section{Carbon gain from herbivorous versus carnivorous feeding}

To assess the relative importance of algal food and copepod prey, results on gut fluorescence and mandibles were converted into carbon units to obtain a common currency (Fig. 8). Although based on several assumptions, this exercise in essence supports the notion that in northern waters, Meganyctiphanes norvegica is primarily a carnivore, but also shows that grazing, even in their daytime habitat, may represent a significant food intake. In more detail, the results from Oslofjorden suggest that (1) herbivorous and carnivorous food intake was of the same order of magnitude during spring (March and May), including high gain from daytime feeding on algal food in deep water; (2) nocturnal migrations to upper layers during summer (August) was rewarded by high food intake from predation on surface copepods, with no contribution from herbivorous feeding; and (3) feeding conditions during winter were at a seasonal low at the deepest site, while very good at the shallower site where overwintering Calanus spp. were cropped during daytime. As mentioned above, the premium winter feeding con- 


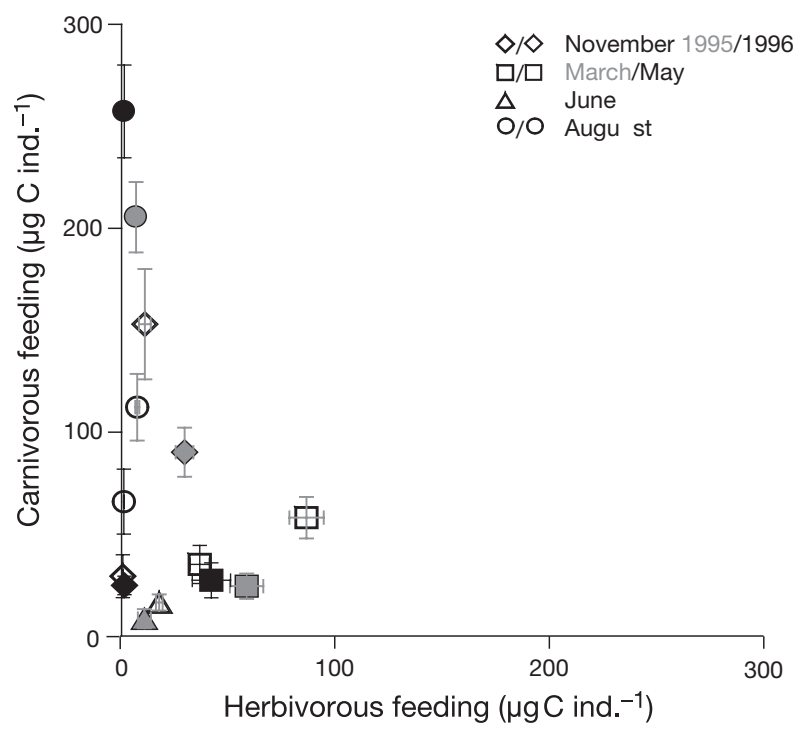

Fig. 8. Meganyctiphanes norvegica. Estimated carbon equivalents in stomach content from copepod and algal food items at day (open) and night (filled) at Stn S (gray) and Stn D (black). Error bars denote SE

ditions at Stn $\mathrm{S}$ are substantiated by other studies. In the same location, Bagøien et al. (2000) on average found 3.8 mandibles of overwintering Calanus in stomachs from $M$. norvegica sampled during the day from late September 1996 to February 1997. According to the conversion factors used in the present paper, this would represent a carbon contribution of $380 \mu \mathrm{gC}$ ind. ${ }^{-1}$ from Calanus spp. alone (other prey items were not addressed in that study).

In the present study, the omnivorous krill Meganyctiphanes norvegica appeared partly as a selectively feeding carnivore. However, the results underlined its very versatile feeding biology, entailing shifts between algal and animal prey, between specific prey taxa, between various food sources during day and the night, as well as seasonal (or more incidental, shortterm) and site-specific feeding patterns. A more comprehensive analysis of feeding conditions would need to account for the pronounced seasonal variations in day length at high latitudes, as well as different turnover times at different temperature regimes, e.g. the enhanced turnover which would occur in the warm waters inhabited at night in August.

\section{LITERATURE CITED}

Atkinson A, Snÿder R (1997) Krill-copepod interactions at South Georgia, Antarctica, I. Omnivory by Euphausia superba. Mar Ecol Prog Ser 160:63-76

Bagøien E, Kaartvedt S, Øveraas S (2000) Seasonal vertical migration of Calanus spp. in Oslofjorden. Sarsia 85: 299-311

Båmstedt U, Karlson K (1998) Euphausiid predation on copepods in coastal water of the Northeast Atlantic. Mar Ecol Prog Ser 172:149-168

Barange M, Gibbons MJ, Carola M (1991) Diet and feeding of Euphausia hanseni and Nematoscelis megalops (Euphausiacea) in the northern Benguela Current: ecological significance of vertical space partitioning. Mar Ecol Prog Ser 73:173-181

Beyer F (1992) Meganyctiphanes norvegica (M. SARS) (Euphausiacea) a voracious predator on Calanus, other copepods, and ctenophores, in Oslofjorden, southern Norway. Sarsia 77:189-206

Buchholz F, Buchholz C, Reppin J, Fischer J (1995) Diel vertical migrations of Meganyctiphanes norvegica in the Kattegat: comparison of net catches and measurements with Acoustic Doppler Current Profilers. Helgol Meeresunters 49:849-866

Dagg MJ, Gill DW (1980) Natural feeding rates of Centropages typicus females in the New York Bight. Limnol Oceanogr 25:597-609

Dagg MJ, Walser WE Jr (1987) Ingestion, gut passage, and egestion by the copepod Neocalanus plumchrus in the laboratory and in the subarctic Pacific Ocean. Limnol Oceanogr 32:178-188

Dilling L, Wilson J, Steinberg D, Alldredge A (1998) Feeding by the euphausiid Euphausia pacifica and the copepod Calanus pacificus on marine snow. Mar Ecol Prog Ser 170:189-201

Falk-Petersen S, Hopkins CCE (1981) Zooplankton and sound scattering layers in North Norwegian fjords: interactions between fish and krill shoals in a winter situation in Ullsfjorden and Øksfjorden. Kieler Meeresforsch Sonderh 5: 191-201

Falk-Petersen S, Hagen W, Kattner G, Clarke A, Sargent J (2000) Lipids, trophic relationships, and biodiversity in Arctic and Antarctic krill. Can J Fish Aquat Sci 57 (Suppl 3):178-191

Gibbons MJ (1993) Vertical migration and feeding of Euphausia lucens at two $72 \mathrm{~h}$ stations in the southern Benguela upwelling region. Mar Biol 116:257-268

Gibbons MJ, Pillar SC, Stuart V (1991) Selective carnivory by Euphausia lucens. Cont Shelf Res 11:625-640

Gonzáles HE, Smetacek V (1994) The possible role of the cyclopoid copepod Oithona in retarding vertical flux of zooplankton faecal material. Mar Ecol Prog Ser 113: 233-246

Goswami SC, Padmavati G (1996) Zooplankton production, composition and diversity in the coastal waters of Goa. Indian J Mar Sci 25:91-97

Greene CH, Stanton TK, Wiebe PH, McClatchie S (1991) Acoustic estimates of Antarctic krill. Nature 349:110

Hjelmseth K (1998) Fødebiologi og vertikalfordeling hos Meganyctiphanes norvegica i ytre Oslofjord. MSc thesis, University of Oslo

Karlson K, Båmstedt U (1994) Planktivorous predation on copepods. Evaluation of mandible remains in predator guts as a quantitative estimate of predation. Mar Ecol Prog Ser 108:79-89

Kirkerud LA (1975) Konsentrasjonen av kopper, sink, bly og kadmium (delvis også jern) målt i zooplankton-arter fra Oslofjorden og Skagerrak. MSc thesis, University of Oslo (in Norwegian)

Lindem T, Al Houari D (1993) EP500 - a system for processing and presentation of echogram data produced by the Simrad EY500/EK500 echo sounders. ICES CM (1993)/B 
Mauchline J (1980) The biology of euphausiids. Adv Mar Biol 18:373-623

Mauchline J, Fisher LR (1969) The biology of euphausiids. Adv Mar Biol 7:1-454

Mayzaud P, Virtue P, Albessard E (1999) Seasonal variations in the lipid and fatty acid composition of the euphausiid Meganyctiphanes norvegica from the Ligurian Sea. Mar Ecol Prog Ser 186:199-210

McClatchie S (1985) Feeding behaviour in Meganyctiphanes norvegica (M. Sars) (Crustacea:Euphausiacea). J Exp Mar Biol Ecol 86:271-274

Ohman MD (1988) Behavioral responses of zooplankton to predation. Bull Mar Sci 43:530-550

Olsen EM (1996) Eksperimentelle studier av fødeinntak hos den carnivore copepoden Paraeuchaeta norvegica (Boeck). MSc thesis, University of Oslo (in Norwegian)

Omori M, Ikeda T (1984) Methods in marine zooplankton ecology. John Wiley \& Sons, New York

Onsrud MSR, Kaartvedt S (1998) Diel vertical migration of the krill Meganyctiphanes norvegica in relation to physical environment, food and predators. Mar Ecol Prog Ser 171: 209-219

Ottesen GO (1995). Næringsøkologi hos to predaterende kopepoder, Chiridius armatus (Boeck) og Euchaeta norvegica (Boeck), i nordnorske farvann. MSc thesis, University of Tromsø

Pearcy WG, Hopkins CCE, Grønvik S, Evans RA (1979) Feeding habits of cod, capelin and herring in Balsfjorden, Northern Norway, July-August 1978: the importance of euphausiids. Sarsia 64:269-277

Perissinotto R, Pakhomov EA (1996) Gut evacuation rates and pigment destruction in the Antarctic krill Euphausia superba. Mar Biol 125:47-54

Price H J (1989) Swimming behaviour of krill in response to algal patches: a mesocosm study. Limnol Oceanogr 34: 649-659

Price HJ, Boyd KR, Boyd CM (1988) Omnivorous feeding behavior of the Antarctic krill Euphausia superba. Mar Biol 97:66-77

Editorial responsibility: Otto Kinne (Editor),

Oldendorf/Luhe, Germany
Sameoto DD (1980) Relationships between stomach contents and vertical migration in Meganyctiphanes norvegica, Thysanoëssa raschii and T. inermis (Crustacea Euphausicea). J Plankton Res 2:129-143

Sargent JR, Falk-Petersen S (1981) Ecological investigations on the zooplankton community of Balsfjorden, northern Norway: lipids and fatty acids in Meganyctiphanes norvegica, Thysanoessa raschii and T. inermis during midwinter. Mar Biol 62:131-137

Sars GO (1903) An account of the crustacea of Norway. Vol IV. Copepoda Calanoida. Bergen Museum

Sars GO (1918) An account of the crustacea of Norway. Vol VI. Copepoda Cyclopoida. Bergen Museum

Simard Y, Lacroix G, Legendre L (1986) Diel vertical migrations and nocturnal feeding of a dense coastal krill scattering layer (Thysanoessa raschi and Meganyctiphanes norvegica) in stratified surface waters. Mar Biol 91:93-105

Strickland JDH, Parsons TR (1972) A practical handbook of seawater analysis. Bull Fish Res Board Can 167:1-310

Torgersen T (2001) Visual predation by the euphausiid Meganyctiphanes norvegica. Mar Ecol Prog Ser 209:295-299

Vedal J (1997) Dyreplankton ved overflaten og i dypere vannlag: døgnlige variasjoner i vertikalfordeling og tilknytning til potensiell næring. MSc thesis, University of Oslo

Viitasalo M, Kiørbo T, Flinkman J, Pedersen LW, Visser AW (1998) Predation vulnerability of planktonic copepods: consequences of predator foraging strategies and prey sensory abilities. Mar Ecol Prog Ser 175:129-142

Virtue P, Mayzaud P, Albessard E, Nichols P (2000) Use of fatty acids as dietary indicators in northern krill, Meganyctiphanes norvegica, from northeastern Atlantic, Kattegat, and Mediterranean waters. Can J Fish Aquat Sci 57 (Suppl 3):104-114

Wiborg KF (1954) Investigation on zooplankton in coastal and offshore waters of western and northwestern Norway. Fiskerddir Skr Ser Havunders 11:56-65

Zar JH (1996) Biostatistical analysis. Prentice-Hall International, Englewood Cliffs, NJ

Submitted: March 12, 2001; Accepted: July 5, 2001

Proofs received from author(s): February 18, 2002 